\title{
メラミンの生成反応および加熱縮合物の加水分解によって生ずる化合物 (シアノメラミン,グアニルメラミンおよびシアメルル酸等)の分離定量の検討
}

(昭和 35 年 10 月 27 日受理)

滝本雅 祥*

ジシアンジアミドを加熱してメラミンを得る場合の中間生成物として証明されたシアノメラミン，グアニルメラミンを 中心に，同侍に共存を予想される他の物質との分離定舅法を榆討し，イオン交換クロマトグラフィーではアンバーライト

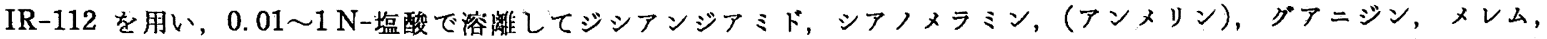
メラミン, ビグアニド、グアニルメラミン,メラムが順次分離出来ることを認めた。これらの混合物を同時に吸光光度法 で定量する場合には溶解度の極めて小さいメラム,メレムを除去した試料溶液を $0.1 \mathrm{~N}$-程酸酸性として 236, 240, 250, $257 \mathrm{~m} \mu$ の 4 波長を選んで測定すれば, グアニジン, ビグアニドがほとんど牮視でき, ジシアンジアミド, メラミン, シ アノメラミン,グアニルメラミンを定量し得る。

またメラミン, メラム，メレム，メロン等を加水分解した際に生ずるアンメリン，アンメリド，シアヌル酸，シアメル ル酸の混合物の分觊にアンバーライトIRA-411 を用いてこれらを吸着させた後、それぞれ $0.05 〜 0.1 \mathrm{~N}-; 0.5 \mathrm{~N}-; 1 \mathrm{~N}-$ 水酸化ナトリウムで溶離を行ない完全に分綮できた。

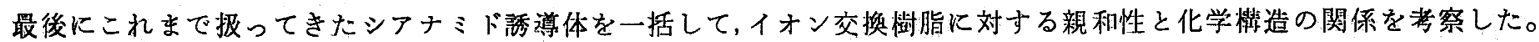

\section{1 緒言}

これまで第 2〜9 報1)で石灰窒素から比較的簡単な化学的処 理※1で生成され共存の可能性の多い非環状拉よび環状シアナミ ド誘導体の分離定量(イオン交換クロマトグラフィーによる分離, 可視・紫外吸光分析）について報告してきたが，本報では更にジ シアンジアミドの溶融によるメラミン生成反応の中間過程に生成 すると報告されているシアノメラミンとグアニルメラミン2)を中 心とした種々誘導体の混合物についての分離定量の検討とメラミ ンの加熱脱アンモニア縮合物中メレム，メロンの加水分解によっ て生ずるシアメルル酸を中心とした加水分解物の分離定量の検討 について記した。

常圧または液体アンモニア加圧下でジシアンジアミドを加熱し てメラミン化反応を行ならとき，中間生成物にシアノメラミン， グアニルメラミンを生ずることが倉林, 柳谷2)により, 初めて報 告された。この際原料のジシアンジアミド, 主生成物であるメラ<smiles>NC1=NC(N)C=NC(N)N1</smiles><smiles>NC1=NC(N)N=C(N)NC(NC(N)N)N1</smiles><smiles>[As]C=[Te]</smiles><smiles>C1CCC1</smiles>

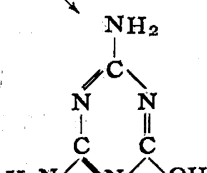<smiles>C=[IH]</smiles>
$\mathrm{H}_{2} \mathrm{~N} / \mathrm{N}_{\mathrm{N}} \mathrm{C}_{\mathrm{OH}}$ アンメリン

†本報を「ジ゚ナミド誘導体の分離定 法の研究 (第 10 報)」とする.

* 日本カーバイド工業怢式会社魚津工場 研笕所：富山罢魚津汸本新。
ミンはもちろん,グアニジン，ビグアニドも生成し，時にはメラ ム,メレム等（倉林らは水不溶物として扱っている）当生成する。 $\mathrm{NH}$

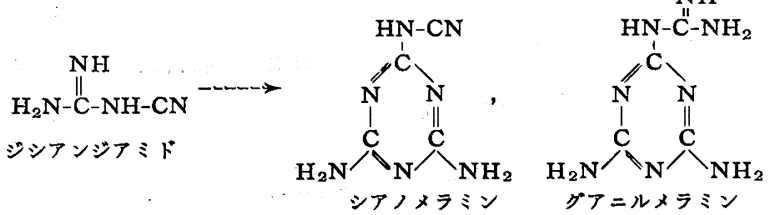

両氏はこれらを通常の化学的方法で分離し定量を行なったが，そ の操作は面倒である。しかしこれらの物質はそれぞれ塩基度が異 なるためにイオン交換クロマトグラフィーにより分離が期待され る。

一方メラミンおよびその脱アンモニア䑿合物であるメラム, メ レム, メロンをアルカリで加水分解すると，メラミン，メラムか らは渐次アンメリン，アンメリド，シアヌル酸が生成し，メレ ム, メロンからは漸次シアメルル酸, アンメリド, シアヌル酸が 生成する。これらの加水分解生成物が混合している場合, アンメ

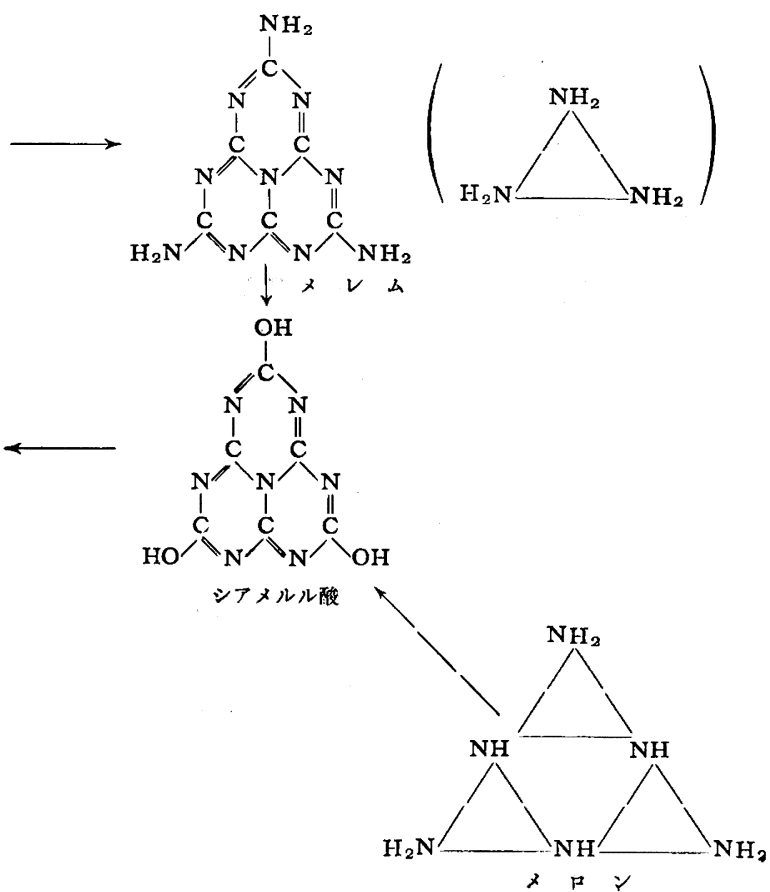


リン,アンメリドとシアヌル酸の分離は塩基性，酸性物質である 相違により陽イオン交換樹脂（または陰イオン交換樹脂）で簡単 に分離できるが1d)，シアヌル酸とシアメルル酸はともに 3 個の水 酸基を有する酸性物質で化学性がよく似ているため共存の場合分 離定量が難かしい。しかしながらイオン交換クロマトグラフィー では比較的容易に分離できることを知った。

\section{2 実験および結果}

\section{$2 \cdot 1$ 実験装置および操作法}

i）イオン交換樹脂カラム：アンバーライトIR-112 または IRA-411（多孔性陽イオン，陰イオン交换樹脂）を 48〜80メッ シュに粉磔して長さ $18 \mathrm{~cm}$, 内径 $0.8 \mathrm{~cm}$ のカラムに充填し遊離 型として用いた。

ii）吸光度测定用装置：陚料溶液の紫外吸収测定に使用した 分光器は鳥津光電分光光度計 QR-50 型で, セルには厚さ $10 \mathrm{~mm}$ の水晶セルを用いた。

iii）分離操作法：試料溶液をカラムに通して樹脂に吸着させ, 水およびしだいに濃度を增した塩酸, または水酸化ナトリウム溶 液を每分約 $1.5 \mathrm{ml}$ の流速で通し流出液をフラクションコレクタ 一で $10 \mathrm{~m} l$ ずつ集め.て波長 $226 \sim 230 \mathrm{~m} \mu$ で吸光度を測定した。

\section{$2 \cdot 2$ シアノメラミン, グアニルメラミン※2およびメラミン等 との分離と定量}

2.2.1 紫外吸収スペクトル i) シアノメラミン：図1のよ 弓に中性溶液では $252 \mathrm{~m} \mu$ に極大吸収点を有するが，酸性になる に従い極大点が徐々に短波長側に移るとともに吸収の強さむやや 減少し，遂には消失して短波長に吸収の深いなだらかな曲線とな る。アルカリ性では極大吸収点は $246 \mathrm{~m} \mu$ に現われるがアルカリ 濃度にほとんど影響されない。

ii）グアニルメラミン：図 2 のように酸性溶液では $222 \sim 3 \mathrm{~m} \mu$ に強い第 1 の極大吸収点を，また 256〜 $7 \mathrm{~m} \mu$ にはそれより弱い

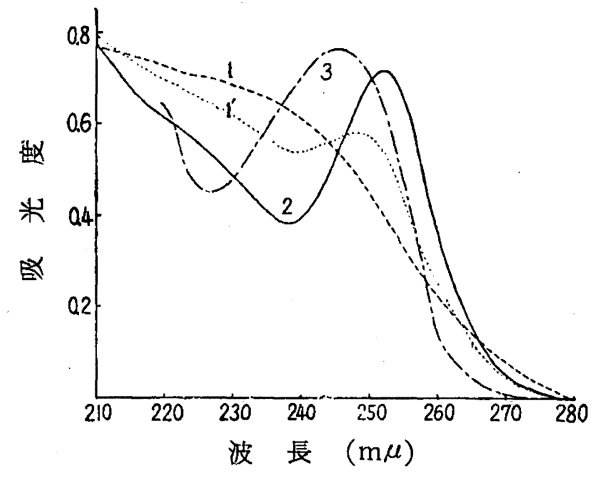

図 1 シアノメラミンの吸収スペクトル

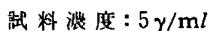

1. $0.5 \mathrm{~N}-\mathrm{HCl}$ 溶没 2 .中性水溶派

$1^{\prime} .0 .1 \mathrm{~N}-\mathrm{HCl}$ 溶液 3. $0.5 \mathrm{~N}-\mathrm{NaOH}$ 浴液

1） a）滝本, 沢田, 工化 $63,799,967$ (1960),(第 2, 3 報) b) 滝本，平野，日化 $81 ， 1414 ， 1418(1960)$,(第4,5報) c）滝本，八尾，工化 63，1938，1941(1960)，(第6,7報)。 d) 滝本, 工化 $64,1234,1452$ (1961), (第 8,9 報).

2）倉林，柳谷，工化 $56 ， 426$ (1953)；58，762 (1955)；62, 1872 (1959)

※1 特殊な原子またはラジカルの導入や特殊な反応を行なわ， ず，加熱あるいは酸，アルカリによる分解等の極めて一般 的な処理を指す。

※2 試料はいずれる東工試會林氏よりいただいた。
第 2 の極大吸収点を有するが，中性に近つくにつれ両極大吸収点 は漱次短波長側に移行し特に第 2 極大吸収は弱まって中性浴液て はこの吸収がほとんど平坦となり僅かに 250〜252 m $\mu$ 極大が みられる程度となり；第 1 極大吸収点は $210 \mathrm{~m} \mu$ 以下となる。ア ルカリ性溶液ではその濃度にかかわらすスベクトルの変化がほと んどなく $225 \mathrm{~m} \mu$ に強度もほぼ等しい極大吸収がみられる。

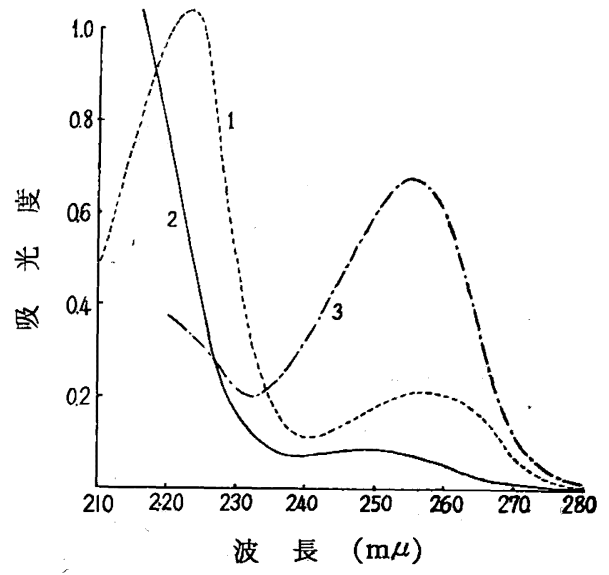

図 2 グアニルメラミンの吸收スペクトル 試料浱度: $5 \gamma / \mathrm{m} l$

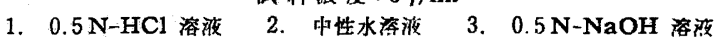

2.2.2 イオン交換クロマトグラフィーによる分離 シアノメ ラミン,グアニルメラミンおよびメラミンの水溶液試料を混合し てアンパーライト IR-112 のカラムに通して吸着させ希塩酸で溶 離を試みたところ, 罒 3 のようにシアノメラミンは $0.1 \mathrm{~N}$-塩酸 で, メラミンは $0.5 \mathrm{~N}$-塩酸で，またグアニルメラミンは $2 \mathrm{~N}-$ 塩 酸で溶離しいずれる97\% 以上の回収率を示した。

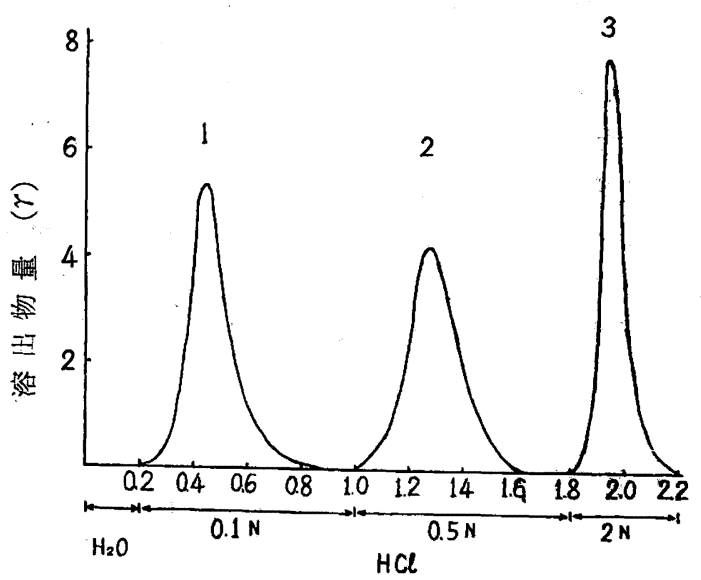

溶出液量 $(l)$

园 3 メラミン, シアノメラミン, グアニルメラミンの分離

試 料：各 $0.2 \mathrm{mg}$

イオン交换树脂：アンバーライト IR-112 48〜80 メッシュ カラム: $18 \times 0.8 \phi \mathrm{cm}$, 溶離速度: $1.5 \mathrm{ml} / \mathrm{min}$ 娜定波辰 : $230 \mathrm{~m} \mu$

1. シアノメラミン 2. メラミン 3. グアニルメラミン

しかしながら先にも述べたよらにシアノメラミン,グアニルメ ラミンの生成する場合ジシアンジアミド，グアニジシ，ビグアニ ド,メラミン,メラム, メレムや時にはアンメリンの副生するこ とが考えられる。これらの混合試料について前と同様に分離を行 なったが溶離塩酸濃度を非常に希薄にして $0.01 \mathrm{~N} \sim 1 \mathrm{~N}$-塩酸を 用いれば，図 4 のようにジシアンジアミド, シアノメラミン, ア ンメリン,グアニジン,メレム,メラミン, ビグアニド,グアニ 


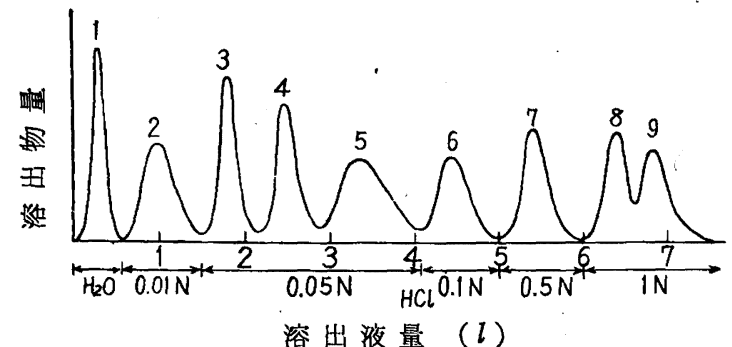

溶出液量 $(l)$

図 4 ジシアンジアミド溶融により生成を予想される成分の分離 湖定条牪前図と同し

ただし非環状敘道体はニトロプルシドナトリウム・フ

エリシアン化カリウム試楽炕よる発色によった。

$\begin{array}{llll}\text { 1. シシシアンシアミド } & \text { 2. シアノメラミン } & \text { 3. アンメリン }\end{array}$

4. ク゚アニジン, 5. メ レA. $6 . \times$ ム

7. ビグアニド 8. グアニルメラミン 9. メラム

ルメラミン,メラムが順次溶離されることを知った。

$2 \cdot 2 \cdot 3$ 吸光光度法による同時定量 吸収を有する混合試料の 成分数が余り多くない場合には各成分を分離せずに第 9 報 ${ }^{1 \mathrm{~d}}$ にも 記した次の連立方程式で求める方法も考えられる。

$$
\text { - } A_{n}=\kappa^{n}{ }_{\mathrm{I}} C_{\mathrm{I}}+\kappa^{n}{ }_{\mathrm{II}} C_{\mathrm{II}}+\cdots \cdots+\kappa^{n}{ }_{\mathrm{N}} C_{\mathrm{N}}
$$

ただし I, II ……N は混合成分， $n$ は選択波長 $(n$ 個)， $A$ は混 合成分の吸光度, $\kappa$ は吸光係数, $C$ は各成分の濃度である。

この試料の場合シアノメラミン，グアニルメラミン，メラミ ン, ジシアンジアミド,:グアニジン, ビグアニド,.メラム, メレ ムの 8 種の物質の混成が予想されるが，このうちメラム，メレム は極めて溶解度が小さいので水溶液に打ける溶解度差を利用して ほとんど分離される2)。一方ジシアンジアミド，グアニジン，ビ グアニドの紫外吸収スペクトルは図5のようにジシアンジアミ ド，ビグアニドには $240 〜 250 \mathrm{~m} \mu$ 以下にかなり強い吸収が見ら れるがグアニジンにはほとんど吸収がない，ビグアニドについて る酸性溶液の場合 $235 \mathrm{~m} \mu$ 以上の僅かな吸収を無視すれば比較的 生成量の少ないグアニジン，ビグアニドは測定から除外すること ができる。したがってここでは最す適当と思われる $0.1 \mathrm{~N}$-塩酸 溶液の場合のジシアンジアミド, メラミン, シアノメラミン, グ アニルメラミンの 4 成分の測定と, シアノメラミン, グアニルメ ラミンのスペクトルの pHによる変動が少なく, かつ測定に都合 のよい極大吸収を有する $0.1 \mathrm{~N}$-水酸化ナトリウム溶液の場合に ついて検討した。

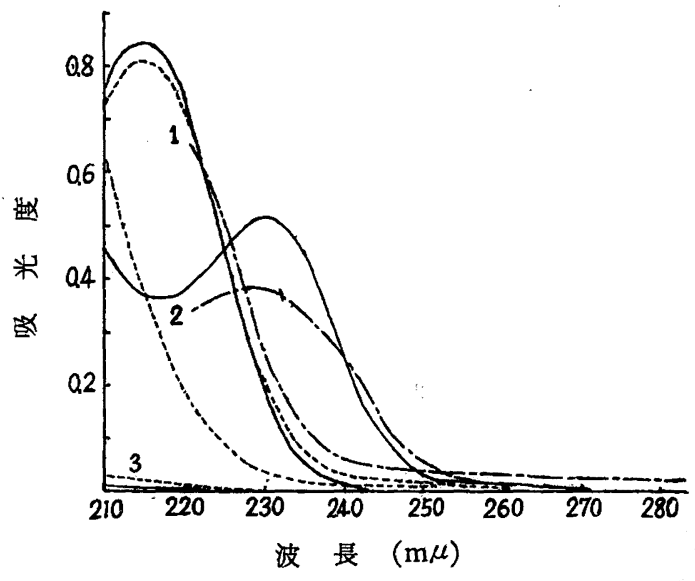

四 5 ジシアンジアミド, グアニジン，ビグアニド の吸收スペクトル

武 料: 各 $5 \gamma / \mathrm{ml}$

$\begin{array}{lll}\text { 1. ジシフンジアミド } & \text { 2. ビグフニド } & \text { 3. ク゚アニジン }\end{array}$

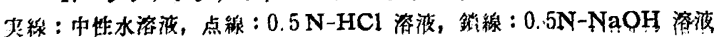

$0.1 \mathrm{~N}$-塭酸溶液の場合図 6 K示したよ5に適当と思われる 236 (メラミンの $\lambda_{\max }$ ), 240 (シアノメラミン, グアニルメラミンの $\left.\lambda_{\min }\right), 250$ (シアノメラミンの $\left.\lambda_{\max }\right), 257$ (グアニルメラミン の $\lambda_{\mathrm{max}}$ ）の 4 波長を選択して裴 1 の各成分の吸光俰数を予じめ 求めておき混合試料につき各成分を測定した結果を表 2 に示し た。

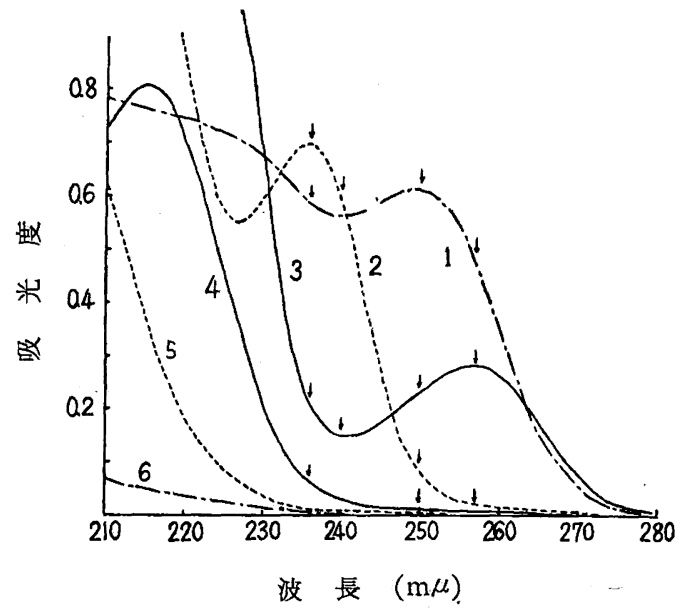

因66 成分の吸収スペクトル（1） $0.1 \mathrm{~N}-\mathrm{HCl}$ 溶波

1. シアノメラミン $5.6 \gamma / \mathrm{ml} \quad$ 4. シシシアンジアミド $5.2 \gamma / \mathrm{m} l$

2. メラミン $7.9 \gamma / \mathrm{ml} l$ 5. ビグアニド (一硝酸堨) $5.1 \gamma / \mathrm{ml}$

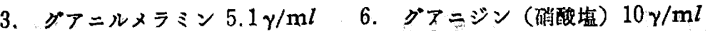
矢印は塄択波辰

表 1 . 各成分の吸光係数 ( $0.1 \mathrm{~N}-\mathrm{HCl}$ 溶液)

\begin{tabular}{|c|c|c|c|c|}
\hline & $236 \mathrm{~m} \mu$ & $240 \mathrm{~m} \mu$ & $250 \mathrm{~m} \mu$ & $257 \mathrm{~m} \mu$ \\
\hline ジシアンジアミド & $8 .{ }^{\circ}$ & 2.7 & 0.2 & $0.0^{7}$ \\
\hline$x=ミ ン$ & 81 & 69 & 9.3 & 2.8 \\
\hline シフノメラミン & 107 & 103 & 111 & 88 \\
\hline グアニルメラミン & 41 & 30 & 46 & 54 \\
\hline
\end{tabular}

表 2 混合試料分析例（各成分 $4 r \sim 0.5 \gamma / \mathrm{m} l$ )

\begin{tabular}{|c|c|c|c|c|}
\hline & \multicolumn{2}{|c|}{ 武料 $\mathrm{A}$} & \multicolumn{2}{|c|}{ 試料 B } \\
\hline & $\begin{array}{c}\text { 理铪佔 } \\
(\%)\end{array}$ & $\begin{array}{c}\text { 測定健 } \\
(\%) \\
\text { \%) }\end{array}$ & $\begin{array}{c}\text { 理諭优 } \\
(\%) \\
(\%)\end{array}$ & $\begin{array}{c}\text { 測定优 } \\
(\%)\end{array}$ \\
\hline ジシアンジアミド & 25 & $24 .^{2}$ & 40 & $41 .^{\circ}$ \\
\hline 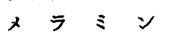 & 25 & 24.8 & 40 & 39.5 \\
\hline シアノメラミン & 25 & $25 .^{4}$ & 5 & 4.8 \\
\hline ク゚アニルメラミン & 25 & 25.6 & 5 & 5.1 \\
\hline 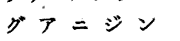 & & . & 5 & - \\
\hline ビグ & & & 5 & - \\
\hline
\end{tabular}

次に $0.1 \mathrm{~N}$-水酸化ナトリウム溶液の場合図 7 のようなス゚ク トルになりビグアニドの吸収もかなり長波長側まで無視できなく なるが，シアノメラミン，グアニルメラミンはそれぞれ 246, $255 \mathrm{~m} \mu$ に大さな極大吸収 $\left(\lambda_{\max }\right)$ を有し，この波長では表のよ 5にメラミンの吸収が微弱となるので,メラミンを含む 3 成分試 料につきメラミンを無視してシアノメラミン，グアニルメラミン を求め表 4 に示したが，メラミンが多くなると誤差が大となった。 $2 \cdot 3$ シアヌル酸, シアメルル酸の分離 $\times 3$

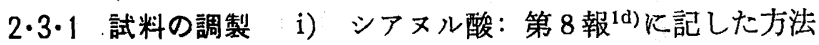
表 33 成分の吸光係数 $(0.1 \mathrm{~N}-\mathrm{NaOH}$ 溶液 $)$

\begin{tabular}{ccc} 
& $246 \mathrm{~m} \mu$ & $255 \mathrm{~m} \mu$ \\
\hline シアノメラミン & 153 & 100 \\
グアニルメラミン & 123 & 169 \\
× ミ ン & 4.8 & $1 .{ }^{\circ}$
\end{tabular}

※3 シアヌル酸は減任下で加熟すると界菲するので，界華法に よる分離も可能である ${ }^{1 \mathrm{~d})} 。$ 


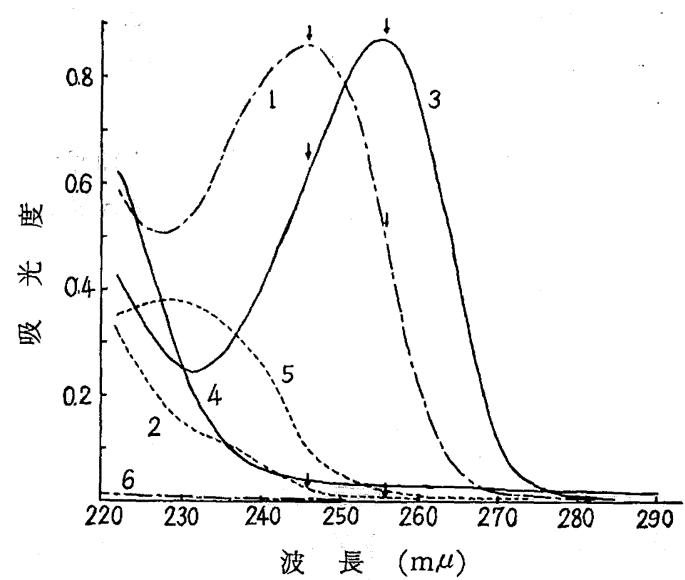

図 76 成分の吸収スペクトル（2） $0.1 \mathrm{~N}-\mathrm{NaOH}$ 溶液

1. シアノメラミン $5.6 \gamma / \mathrm{m} l \quad 4$. シシシアンジアミド $5.2 \gamma / \mathrm{m} l$

2. メラミン $7.9 \gamma / \mathrm{m} l \quad$ 5: ビグアニド (硝酸壏) $5.1 \gamma / \mathrm{m} l$

$\begin{array}{lll}\text { 3. グアニルメラミン } 5.1 \gamma / \mathrm{m} l & \text { 6. グアニジン (确酸垭) } 10 \gamma / \mathrm{m} l\end{array}$ 失印浽択波長

表 43 成分試料 の分析例 各試料 $(\mathrm{I} \sim \mathbb{N})$ ともシアノメラミン, グアニルメラミン含量 $2 \gamma / \mathrm{m} l$ メラミン含量 I $0 \gamma$, II $1 \gamma$, III $2 \gamma, \mathbb{N} 4 \gamma / \mathrm{m} l$ 各武料㨽定値 \% (各成分 $100 \%$ として)

\begin{tabular}{|c|c|c|c|c|}
\hline & \multicolumn{4}{|c|}{ 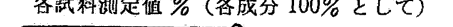 } \\
\hline & I & II & III & $\mathrm{N}$ \\
\hline シアノメラミン & 99 & 102 & 104 & 108 \\
\hline グアニルメラミン & 100 & 99 & 98 & 96 \\
\hline
\end{tabular}

で製造した。

ii）シアメルル酸：粗メレムまたはメロンを水酸化カリウム で約 1 1.5 時間加熱し, 加水分解した後塩酸で中和して析出し た結晶を集め, これにアンモニア性硫酸銅を加兄銅錯塩とした 後, 塩酸で分解し水から再結晶を行なっだ)。

$2 \cdot 3 \cdot 2$ 紫外吸収スペクトル 図 8，9、にシアヌル酸とシアメ ルル酸の中性, 酸性, アルカリ性に扣ける紫外吸収スペクトルを 示した。シアヌル酸の吸収スペクトルは第 8 報1d)述べたように 中性〜酸性ではカルボニル型構造を有するため非常に弱いが，シ アメルル酸では中性, 酸性, アルカリ性ともに $290 \mathrm{~m} \mu$ 至る広箬 围治い吸収を有する。

2.3.3 イオン交換クロマトグラフィーによる分離 シアヌル 酸, シアメルル酸ともに酸性物質であるので陽イオン交換樹脂に

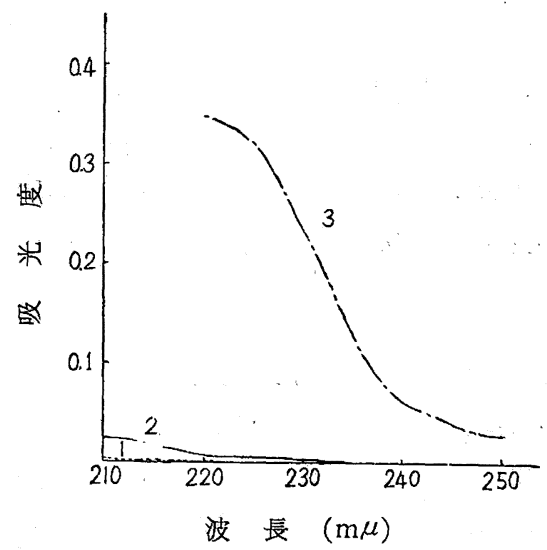

図 8 シアヌル酸の吸収スペクトル

試料滥度: $7 \gamma / \mathrm{m} l$

1. $0.5 \mathrm{~N}-\mathrm{HCl}$ 溶源 2 . 中性水溶腹 $3.0 .5 \mathrm{~N}-\mathrm{NaOH}$ 溶液

3) C. E. Redemann, H. J. Lucas, J.Am. Chem. Soc. 61, 3420 (1939); 62, 842 (1940).

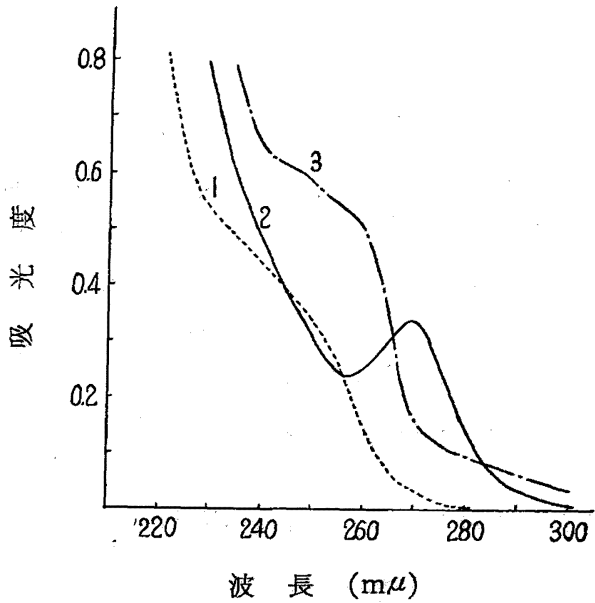

図 9 シアメルル酸の吸収スペクトル 試料浱度: $7 \gamma / \mathrm{m} l$

1. $0.5 \mathrm{~N}-\mathrm{HCl}$ 溶液 2 \% 中性水溶液 $3.0 .5 \mathrm{~N}-\mathrm{NaOH}$ 溶渐

は吸着されない。したがってアンメリン, アンメリド等を含有し ている場合にはこの操作により除去できる。シアヌル酸とシアメ ルル酸の混合溶液を陰イオン交換樹脂アンパーライトIRA-411 に通して吸着させ水酸化ナトリウム溶液で溶出し，波長 $226 \mathrm{~m} \mu$ で吸光度を測定して両成分の分離状態をしらべたが，図 10 のよ うにシアヌル酸は $0.5 \mathrm{~N}$-, シアメルル酸は $1 \mathrm{~N}$-水酸化ナトリウ ムで完全に分離でさ，ほとんどが回収された※4。またアンメリ ン，アンメーリドを含んだ場合にはこれらを $0.1 〜 0.2 \mathrm{~N}$-水酸化ナ トリウムで先に溶出させ得るが，0.05 N-水酸化ナトリウムを用 いれば図 10 のようにこれらす互に完全に分離出来るようになる。 シアヌル酸, シアメルル酸の混合溶液から両者の同時定量を考 えると,アルカリ性溶液ではシアヌル酸の吸収がシアメルル酸の 吸収に扣抒われるため困難であるが，酸性溶液ではシアヌル酸

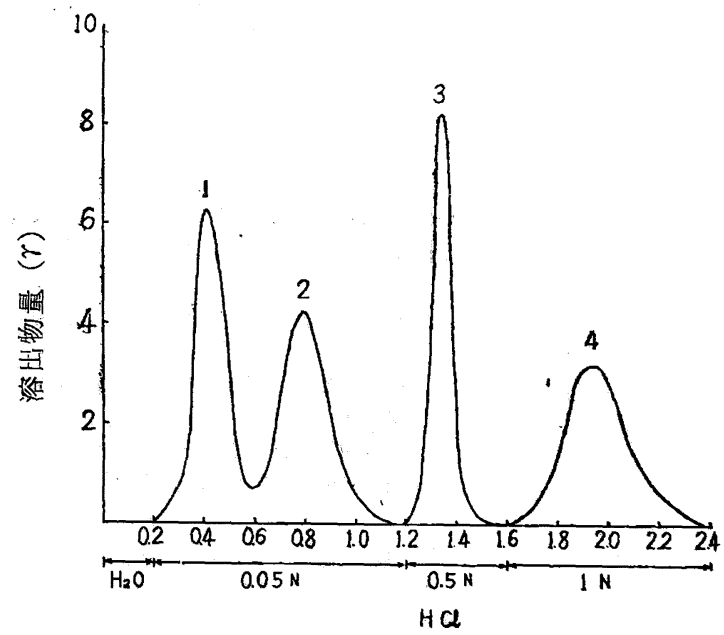

溶出液量 $(l)$

図 10 シアヌル酸、シアメルル酸等の分離

陚 料: 各 $0.2 \mathrm{mg}$

イオン交換楖脂：アンバーシイト IRA-411 48〜80 ネッシュ カラム : $18 \times 0.8 \phi \mathrm{cm}$, 溶離速度 : $1.5 \mathrm{~m} l / \mathrm{min}$, 测定波長 : $226 \mathrm{m \mu}$

1. アンメリン 2. アンメリド

3. シアヌル酸 4. シアメルル

※4 アンバーライト IRA-410 ではシアヌル酸は $0.5 \sim 1 \mathrm{~N}$ の またシメルル酸は $1 \sim 1.5 \mathrm{~N}$-水酸化ナトリウムで溶離され たが，アンバーライト IRA-411 による場合よりも分離が 劣っていた。 
の吸収がほとんどないため，シアメルル酸のみの測定が可能で める。

\section{3 考察}

比校的簡単な※1種々のシアナミド誘導体のイオン交换クロマ トグラフィーによる分離は本報まででほとんど検討し尽した。最 後にこれらの化合物を一括してイオン交換樹脂に対する親和性に ついて考えてみるに，アンバーライト IR-112 のカラム（長さ $20 \mathrm{~cm}$, 内径 $0.8 \mathrm{~cm}$ ) にこれらを吸着させ塩酸で溶出を行なった 場合，直ちに溶離してくるよ5な程酸濃度から分類すると表 5 の ようになる。

裴 5 種 ト化合物のアンバーライト IR-112 に対する親和性 IR-112 非吸蔽物梊 㹣イオン交換樹脂

IR-112 吸清物留 溶離㙁酸潆度

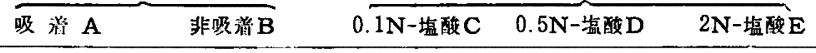

シアナミト ジシアンジフミド シアノメラミン グアニジン ビグアニド シアノ尿奖尿素 アンメリングフニル尿慗グアニルメラミン シアヌル酸 (チオ尿察) アンメリトメラミンメラム シアメルル酸 メレムム

この結果は明らかに構造上から考えられる酸性または塩基性や 化学性とも一致し， $\mathrm{A}$ 群は酸性， B 群は中性， $\mathrm{C}$ 群は両性であり, また Dおよび $\mathrm{E}$ 群は塩基性ではめるがそれそれ 1 酸性および 2 酸 性塩基の挙動を示している。一般に電気的陰性基であるシアノ 基, 水酸基（またはカルボニル基）を有する化合物は酸性を, 電 気的陽性基であるアミノ基またはグアニル基を有する化合物は塩 基性を示しているが; トリアジン環に結合する場合，アミノ基， 水酸基の数が異なっても 1 価の酸, 塩基の挙動を呈し, したがっ
てアンメリン, アンメリドはアミノ基, 水酸基（またはカルボニ

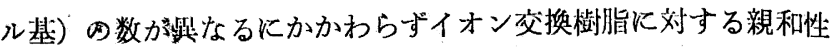
はあまり変わらない。また非環状化合物は環状化合物よりイオン 交換樹脂に対する親和性が弱い傾向がみられ（図 4)，たと党ば $\mathrm{D}, \mathrm{E}$ 群の親和性がグアニジンくメラミン，ビグアニドくグアニ ルメラミンくメラムとなっているが, 特に構造上両性的性質を有 すると考えられる B 群は同様な構造に属するC 群よりその性質が 非常に弱いことが樹脂に対する親和性からも明らかである。トリ

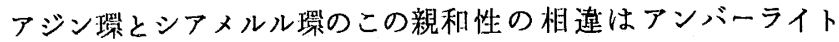
IR-112 に拈けるメレム, メラミンの溶離順序（図 4) と, アン バーライト IRA-411 に持けるシアヌル酸, シアメルル酸の溶離 順序（図 10）から考文併せてトリアジン環の方が幾分塩基として の親和性を有していることがうかがえる※5。これらシアナミド誘 導体の構造とイオン交換樹脂に対する親和性の関係については稿 を改めて更に広く詳細に報告する予定である。

なおシアナミド誘導体混合物から非環状誘導体の大部分を除去 するのに第 7 報に述ベたニトロプルシドナトリウム・フェリシア ン化カリウム試薬を加えて錯陰イオンを形成させ陰イオン交換樹 脂に通して吸着させる方法も場合によっては有効である。

（昭和 36 年 1 月 19 日クロマトグラフィー討論会で一部講演） 終りに貴重な試料をいただいた東工試倉林氏，発裴を許可され

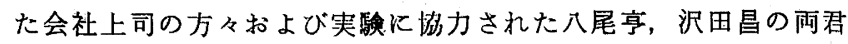
に厚く感謝する。

※5 シアメルル酸はシアヌル酸より酸解嵟定数が大きい3)。

\title{
酢酸ビニル合成用酸化金属触媒の反応過程における活性および組成の経時変化†
}

\author{
(昭 和 35 年 9 月. 9 日受理)
}

$$
\text { 宮 沢 三 郎* }
$$

酸化金属触媒の酢酸ビニル合成反応過程における活性および組成の経時变化は, 一いずれ,の触媒の場合でも反応の初期に おいて著しい。この間に活性は零から極大に達し，ついでこの両変化はともに緩やかとなる。またこの期間に炭素の生成 す認められる。

これより酸化金属触媒の活性減衰の原因は，触媒の組成変化と触媒活性面の堆䅡炭素による污染がその主要なるのであ ると推定した。

一方，定常状態に招ける酸化金属触媒の主体をなす亜鉛塭の化合形態は，大略 $3 \sim 4 \mathrm{ZnO} \cdot \mathrm{Zn}(\mathrm{AcO})_{2}$ の組成を有するオ キシ酢酸塩であることを知った。

現行の実用触媒 $\left[\mathrm{Zn}(\mathrm{AcO})_{2}\right.$ 含浸活性炭了ではこれが $2 \mathrm{ZnO} \cdot 3 \mathrm{Zn}(\mathrm{AcO})_{2}$ で, 酢酸含有量ははるかに多いオキシ塩であ る。このオキシ塩は現用触媒がその $\mathrm{Zn}(\mathrm{AcO})_{2}$ の活性炭への含浸過程で, 加水分解を受けた結果であって, 反応過程中 はほとんど変化しない。

要するに酸化金属触媒でる現用酢酸覀鉛含漫活性炭触媒でも活性の本体は全然同一で $\mathrm{ZnO}$ と $\mathrm{Zn}(\mathrm{AcO})_{2}$ との共存体で ある。たた異なるのは両者の量比である。

\section{1 緒言}

前報1)に扎いては，ZnO を主触媒とし，これに約 30 種の酸化 金属を助触媒とする 2 元またはそれ以上の混合触媒の組成と活性 との関係をしらべた結果, 現行の実用触媒に数倍する初期活性を

†本報を「酶酸ビニル合成用酸化金属触媒研究（第 2 報）」と する．前報在化 $61 ， 614$ (1958) を第 1 報とする.

* 東京工業大学付属工高専攻科：東京都港区西艺浦.

1) 宮沢, 工化 61,614 (1958).
有する数種の優秀触媒を見出したことを報告した。

本報に颃いては引続き，これら触媒の反応過程中の活性および 組成の経時変化をしらべ，主触媒をなす亜鉛塩の化合形態を決定 し，ついで活性減衰の原因を推定した。

\section{2 反応過程における活性および組成の経時変化}

\section{$2 \cdot 1$ 実験法および反応条件}

实験装笛は，反応管の雷気炉を離脱し易い上うにしたことと， 